\title{
THE TRANSCENDENT UNITY BEHIND THE DIVERSITY OF RELIGIONS AND RELIGIOSITY IN THE PERSPECTIVE OF PERENNIAL PHILOSOPHY AND ITS RELEVANCE TO THE INDONESIAN CONTEXT
}

\author{
M. BAHARUDIN ${ }^{1}$, MUHAMMAD AQIL LUTHFAN 2 \\ ${ }^{1}$ Universitas Islam Negeri Raden Intan Lampung \\ ${ }^{2}$ Universitas Islam Negeri Walisongo Semarang
}

\begin{abstract}
This study is conducted to answer an important question: is there any transcendent unity behind the diversity or plurality of religions and religiosity? This question will be answered through perennial philosophy approach. The study found that, according to perennial philosophers, there is a transcendent unity behind the diversity or plurality of religions and religiosity. This transcendent unity is seen in 'the common vision', or what in Islam is called the 'basic message of religion', namely 'submission' to always fear God and live His presence in everyday life. Further, the perennial philosophers argue that the True God is one; therefore, all religions emerging from the One are in principle the same for they come from the same source. In other words, the diversity of religions and religiosity lies only in the exoteric level, and all religions actually have a transcendent unity in the esoteric level. However, in this case, the perennial philosophers do not mean to unify or equate all religions. In fact, they try to open a way to a spiritual ascent through the reviving of the religious traditions in every religion.
\end{abstract}

Corresponding author; email: ${ }^{1}$ baharudinushuludin@gmail.com, ${ }^{2}$ aqilluthfan@walisongo.ac.id 


\section{BAHARUDIN AND MUHAMMAD AQIL LUTHFAN}

Penelitian ini dilakukan untuk menjawab sebuah pertanyaan penting: adakah kesatuan transenden di balik keragaman atau pluralitas agama dengan religiusitas? Pertanyaan ini akan dijawab melalui pendekatan filsafat perennial. Penelitian ini menemukan bahwa, menurut para filsuf perennial, ada kesatuan transenden di balik keragaman atau pluralitas agama dan religiusitas. Kesatuan transenden ini terlihat dalam pandangan bersama, atau apa yang di dalam Islam disebut pesan dasar agama, yaitu tunduk untuk selalu takut kepada Tuhan dan menjalani kehadiran-Nya dalam kehidupan sehari-hari. Selanjutnya, para filsuf perennial berpendapat bahwa Tuhan yang Sejati adalah satu. Oleh karena itu, semua agama yang muncul dari Yang Satu pada prinsipnya sama karena mereka berasal dari sumber yang sama. Dengan kata lain, keragaman agama dan religiusitas hanya terletak pada tingkat eksoteris, dan semua agama benar-benar memiliki kesatuan transenden di tingkat esoteris. Namun, dalam kasus ini, filsuf perennial tidak bermaksud menyatukan atau menyamakan semua agama. Sebenarnya, mereka mencoba membuka jalan menuju pendakian spiritual melalui kebangkitan kembali tradisi keagamaan di setiap agama.

Keywords: esoteric; exoteric; perennial; transcendent.

\section{Introduction}

The term religion, in Indonesian society, is equivalent to aldin (الدين) in Arabic and religi in European language. The word din in Semitic means regulations or law. In Arabic, this word implies mastering, subduing, obedience, debt, recompense, and custom (Nasution 1974; Anshori 1979). According to Harun Nasution, religion does bring regulations as laws that must be obeyed by humans. It takes control of one's self and makes him subservient and obedient to God by living the religious teachings. Religion, further, carries obligations, which if not accomplished, will become a debt or a dependent to a person (Nasution 1974).

This doctrine of obligation and obedience leads to the doctrine of recompense. Those who perform and obey the obliga- 
tion will get a good reprisal from God. Similarly, those who do not will get a bad reprisal from Him (Nasution 1974).

The term agama (religion) is etymologically derived from the Arabic aqoma which means to enforce. Meanwhile, many experts also say that the term religion comes from Sanskrit $a$ and gam; a means not, and gama means a mess or disorganized. Hence, religion means organized or no mess. Fachrudin al-Khairi, however, interprets $a$ as way, and gama as road. Religion, thus, means the ways of walking on the road to reach the mercy of God (M. Arifin 1992).

Agama in English, French, and German is called religion; it in Dutch is called religie; and it comes from the Latin religare or relegere which has several meanings. Augustine argued that relegion consists of the words re and eligare which means to re-elect, i.e. to re-elect a path, from the misguided way to the way of God. Lactantius, in the other hand, argues that relegion consists of re and ligere which means to reconnect the ropes of God and man that broke up for sin. Further, Cicero argues that religion is composed of the word re meaning to read the sacred texts repeatedly, so that the soul is affected by His sanctity (Kuswanjono 2006b).

According to Ahmad Tafsir, religion is a belief system and practice in accordance with that belief. It can also be said that religion is the rule of the inner and outer way of life (Tafsir 1990). Religion among its adherents is believed to bring a sense of security and peace in life because for them it contains the most adequate guidance of life for humans. Religion is a reference to life in its various aspects, including the aspect of social life (Kuswanjono 2006b).

According to Fuad Farid Ismail in one of the Arabic dictionaries, religion is a form of God's provision that directs those who are intelligent-with their own choice toward the provi- 
sion-to the goodness of life in this world and happiness in the hereafter (Ismail 2005).

Arqom Kuswanjono, a lecturer of philosophy at Gadjah Mada University in Yogyakarta, argues that religious thoughts in historical reality have always developed in both theological and philosophical realms. In theological realm, although it is believed that the holy book of a religion comes from the Absolute (the One), it is still open to the possibility of reinterpretation in understanding its messages. The emergence of madhhab or streams, that is rooted in a particular religion or derived from human cultures or thoughts, shows various patterns of religious understanding different and ever-growing (Kuswanjono 2006b). Religion in philosophical realm also becomes an interesting discussion because in every development of the times and thoughts religious discourse always appears. Religion is a universal and eternal theme, existing throughout the ages (perennial) (Kuswanjono 2006b).

The issue of interpretation toward religious teachings becomes important to be studied and elaborated. The empirical reality of human life is always and forever confronted with the diversity of religious understanding. When religion develops into diverse, it becomes very vulnerable to division, such as the triangle conflict of Islam-Christian-Jewish in Palestine, Islam and Hinduism in India, Protestant and Catholicism in Northern Ireland, and religious clashes in other places, (Kuswanjono 2006b) such as in Ambon, Poso, Banjarmasin, Kupang, and other social religious conflicts in Indonesia (Surur 2003). The internal conflicts within a religion also seem to indicate that when a religion, in the exoteric level, claims itself as the only way of truth and blatantly blames other religions, it will lose its essence as a controller of chaos. Conversely, religion becomes the trigger of division or clash. 
Parallel to the above-mentioned explanation, Budhy Munawar Rahman argues that if a religion confronts other religions, it can cause big problems. The problems arise, among others, from the competition of truth claims and, later, salvation claims (Rahman 1995).

From a sociological point of view, indeed this claim of truth and claim of salvation have created various socio-political conflicts that lead to many interreligious wars, which still come true in this modern time. Besides, they also lead one to self-justifying epistemological prejudices for assuming his religion with absoluteness (Rahman 1995).

Citing A.N. Wilson, Munawar Rahman argues: "Marx describes religion as opium of the people; however, religion is more dangerous than the opium. Religion does not make people fall asleep. Rather, it encourages people to persecute their fellows, to glorify their own feelings and opinions rather than the feelings and opinions of others, and to claim for themselves as the owners of the truth"(Rahman 1995).

It is an ambivalent role of religion that, in one hand, among its adherents religion is believed to bring a sense of security and peace in life because for them it contains the most adequate guidance of life for man. Religion is a reference to life in its various aspects, including aspect of social life. On the other hand, religion is regarded as a source of division and unrest. This ambivalence in religious life is also seen in the declaration of the First National Congress of religions in Indonasia held in Yogyakarta in October 1993 as follows:

“... religion, on the one hand, becomes a force for humanitarian, justice and peace movements, but, on the other hand, religious zeal can cause and legitimize divisions and even violence" (Kuswanjono 2006b; Abdurrahman 1993).

The religious ambivalence was also discussed by Abdul $\mathrm{Mu}-$ nir Mulkan, as published in Kedaulatan Rakyat (newspaper) on 
Monday, June 26, 2000 entitled "Agama Dilibatkan, Konflik Kian Ruwet," that is, when religion is involved, conflict will be more complicated. Religion is a guide for mankind to spread peace and provide solutions to the problems of life; however, when it is involved, the problem becomes more difficult. People are even willing to kill each other in the name of religion in which they believe (Kuswanjono 2006b).

Considering the above empirical reality, a question arises: is there any transcendent unity or meeting point behind the diversity of religions and religiousity? As explained above, the question will be answered through the perspective of perennial philosophy, that is, a philosophy which is seen to be able to explain all the problems and events that are essential, as it involves wisdom necessary in living the right life and becomes the essence of all religions and religiousity. This philosophy is very important because it is the only philosophy with which we can understand the conflict of differences among religions many people, including religious scholars, think.

\section{A Glimpse of Perennial Philosophy}

From an etymological point of view, the word perenial is derived from Latin perenis, which is then translated into English as eternal. Therefore, perennial philosophy is also called the philosophy of eternity, as Frithjof Schuon points out: philosophy perennis is the universal ignosis which always has existed and always will exist (Schuon 1993; Kuswanjono 1997). It is a universal mystical knowledge that has existed and will always exist forever.

According to Bambang Sugiarto, the term perennial philosophy or philosophia perennis is often used in various meanings. It could point to a system that uses the term explicitly based on a belief that the theme being discussed and the metaphysical rea- 
soning being used are universal and eternal. Sugiarto argues that in this case, one can remember philosophers, like Steuco and other contemporary philosophers who explicitly use the term philosophia perennis. However, we can also see philosophia perennis in terms of the quality of thought, and here people usually refer to a system, such as what is built by Thomas Aquinas or others who are considered to convincingly set the basis to solve the complicated mysteries of life unlimited by ages and any new philosophy. At least that is what its followers believe.

Quoting Leibniz, Kuswanjono argues that perennial philosophy is a metaphysics that recognizes the divine reality substantial for the living world and minds; it is a psychology that finds something inside the soul and is even identical to the divine reality; and it is an ethic that places the ultimate goal of man on knowledge about the immanent and transcendent foundation of all that exists. According to Huxley, the elements of perennial philosophy can be found in the primitive traditions of a nation, in every world religion, and in fully developed forms of the higher religions (Kuswanjono 2006b).

Perennialism or perennial philosophy or philosophy of eternity is one of the most ancient branches of philosophy. In fact, some thinkers, such as Charles B. Schmit, mention that this branch of philosophy has existed since the time of the earliest thinkers (Schmit 1996). The term perenial usually appears in the discourse of religious philosophy where the point discussed is, first, of God, the Absolute Being, and the source of all beings. The True God is one, so all religions that arise from the One are, in principle, the same for they come from the same source. Secondly, the perennial philosophy wants to discuss the phenomenon of religious diversity critically and contemplatively. Thirdly, it seeks to trace the roots of a person's or group's religiosity consciousness through religious symbols, rituals and experiences (Hidayat and Nafis 1995). 
According to Budhy Munawar Rachman, many names have been given for this perenial philosophy or traditional wisdom, such as scientia sacra or what is in the Islamic tradition called al-hikmat al-ilahiya (the wisdom of God) or whatever fits with the definition given by Frithjof Schuon, i.e. the universal gnosis which always has existed and always will exist. It is a universal mystical knowledge that has always existed and will always exist forever. It is metaphysical knowledge that talks about God, nature, and human being (Rahman 1995; Nasr 2004). This perennial philosophy, for Budi Munawar Rahman, is a philosophy which is seen to be able to explain all essential events, concerning the necessary wisdom in living the righteous life which seems to be the essence of teachings of all the major religions and human spirituality traditions. This philosophy is very important for it is the only philosophy with which its followers may understand the differences among religions.

According to Emanuel Wora, it turns out that philosophers associated with this perenial philosophy have different understanding about the meaning of essential. A perenialist living in the $16^{\text {th }}$ century, Steuco, for example, interprets perennial philosophy as an intellectual tradition that has a synthesis between theology, ancient philosophy, (Schmit 1996) and Christianity. The ancient philosophy meant by Steuco refers not only to Platonism or Neo-Platonism, but also to all other ancient philosophical traditions, including those that existed before Plato. The next philosopher is Aldous Huxley who interprets perennial philosophy as a philosophical tradition consisting of three main branches: metaphysics, psychology and ethics. These three branches are labeled primordial and perennial because they have existed since time immemorial. They are universal and valid throughout the ages. This primordial metaphysics, psychology, and ethics, according to Huxley, lead us to an understanding and awareness 
of God's existence, the Basis of the world and everything in it. Other philosopher, such as Owen C. Thomas, sees perennial philosophy synonymous with the Emissary religious tradition (see Wora 2006, 14).2

Perennial philosophy can also be called a tradition in a sense of al-dinn, al-Sunnah, and al-silsilah. Al-din meant is as a religion covering all its aspects and ramifications. It is called al-Sunnah because perennial bases everything on sacred models that have become a hereditary custom among the traditional society. It is called al-silsilab because perenial is also a chain that connects each period or the stage of life and thought in the traditional world to the source of everything, as seen in sufism. Hence, perennial philosophy-in the sense of this tradition and borrowing the term used by Hossein Nasser-is like a tree; its roots are embedded by waby or divine revelation and from which grows rods and branches throughout the ages.

\section{History and Development of Perennial Philosophy}

The emergence or the birth of perennial philosophy, concerning its period and its creator, is not known. In this case, there are differences of views among scholars regarding the beginning of perennial philosophy. There is a near-certain estimate that this philosophy was born in human intellectual discourse from the time of the first thinkers. However, it is not known to what era it was, and who belonged to the first thinkers (Wora 2006). Aldous Huxley, in his work entitled The Perennial Philosophy, estimates that elements of perennial philosophy began to be written about 25 centuries ago.

${ }^{2}$ Emissary is one of two types of religion proposed by Max Webber. The other type is Exemmplarz. Emissary is represented by the Jewish prophets, Christian apostles, and prophets of Islam, while Exemmarz lies in the saints, Buddhists, tausmies, and other eastern religions. 
Kuswanjono in his study entitled Divinity in Perennial Philosophy: A Reflection on Religious Pluralism in Indonesia states that there are differences of views among scholars regarding the beginning of perennial philosophy. One opinion says that the term perennial philosophy originated from Laibniz because it was used in a letter to his friend named Reimondo dated August 16,1714. The term then was popularized by Adolf Huxley. Nevertheless, Leibniz never applied the term as a name to any philosophical system including his own (Kuswanjono 2006b).

Other view that confirms such an opinion is from Seyyed Hossein Naser stating that the term philosophia perennis (the philosophy of immortality) was once used for the first time in the Western scholarship by Augustine Steuchus in his work entitled De Perenni Philosophia published in 1940. The term was introduced by Leibniz in a letter written in 1715 to refer to a search for the traces of truth among ancient philosophers and to a division of the bright from the dark. Here, Leibniz is actually discussing the perennis of Quaedem Philosophia (Nasr 2004).

Aldous Huxley mentions that Leibniz was the first to use the term (Wora 2006). Emanuel Wora in his book entitled Perenialism: Criticism on Modernism and Postmodernism asserts that Bede Griffiths clearly shows that the period of about the sixth until fifteenth century was the golden era perennial philosophy. According to Wora, Griffiths argues that the development of perennial philosophy emerges not only in the Western world and in the context of Christianity but also in other parts of the world and in other religious traditions.

Furthermore, Emanuel Wora reveals that the golden era of the development of perennial philosophy is not without defect. Steuco's thoughts, which appeared at the renaissance era (see 
Hamersma 1983, 19) ${ }^{3}$ have received much criticism and ridicule, especially from the orthodox Christian who rejected Steuco's perennial philosophy concept and even considered him misguided from faith. This is the traces of the development of perennial philosophy in the perspective of Western scholarship. What actually happens in this Christian Western perspective is not much different from what happens in other religious perspectives.

In this golden era, which in the history of Western world is known as the medieval period, the doctrines of perennial philosophy did penetrate all aspects of human life. One of the most notable conceptions is that the world is understood as a single whole.

Perennial philosophy also referred to as universal wisdom for some complex reasons, gradually began to crumble by the end of the $16^{\text {th }}$ century. One of the dominant factors is the rapid development of the philosophy of materialism ${ }^{4}$ (see Baharudin 2016, 16; Bahtiar 2009, 118-35) This philosophy of materialism brought radical changes to the paradigm of life and thoughts of

\footnotetext{
${ }^{3}$ Renainssance according to Hamersma (1983) is translated as 'rebirth', it occurs in the period circa 1400-1600. At that period, humans seem to be 'reborn' from the medieval period sleep. All western cultures are awakened from a static state that has lasted for 1,000 years beginning in Italy and then in other European countries.

${ }^{4}$ Materialism is a narrow term and a more limited form of naturalism. It generally says that the world is nothing but material, or that the nature and the physical world are one. The term materialism can be defined in several ways including (1): materialism is a theory which says that atomic materials are the elements that make up the nature and (2) that mental aspects and consciusness including all psychical processes are the results of material interactions and can simplified into physical elements. Both definitions have the same implications, though they tend to present a more rational form of materialism. Modern materialists say that nature is an infinite material unity. Nature, including all matter and energy, exist and will always exist. Nature is a hard, touchable, material, and objective reality that can be known by humans. Modern materialists say that matter exists before the soul, and the world of material comes before world of thought.
} 
human society at that time. For example, unlike perennial philosophy which views the universe as a single whole that is united by a transcendent reality and finds its explanation in this reality, philosophy of materialism sees the universe constructed on a mechanistic pattern (Bahtiar 2009). The philosophy of materialism, therefore, almost leaves no room for a transcendent reality. This philosophy was born more or less in the $14^{\text {th }}$ or $15^{\text {th }}$ century rooted in Greek philosophical thoughts, such as Aristotle. The characteristic of Aristotle's philosophy is a belief that man's knowledge is based on the senses or empirical evidences. It was this philosophical concept which later resulted in various philosophical discourses after the $16^{\text {th }}$ century.

Further, the philosophy of materialism also becomes the basis of human philosophy in the modern age (Wora 2006, 37). Some philosophers who have an important role in the birth and development of this philosophy are, among others, Rene Descartes, Francis Bacon, Galileo Galilei, and Isac Newton.

By the eighteenth century, due to the influence of materialistic philosophy, many aspects of reality had been negated leaving only mechanistic systems. The $19^{\text {th }}$ century philosophy is still dominated by the philosophy of materialism which is mechanistic. The philosophy of materialism is so dominating and influencing the modern-day human mindset as it spans from the $16^{\text {th }}$ century (renaissance period) to the end of the $20^{\text {th }}$ century. The dominance of this materialistic philosophy ultimately removes the influence of perennial philosophical doctrines in the intellectual discourse of modern man (Wora 2006).

During the modern age, the discourse of perennial philoso-

${ }^{5}$ Modern comes from the Latin word Modernus which means now. From modern, we find other words, such as modernity and modernism though they actually have no significant difference in meaning. They all convey the same thing, namely the reality of modernity. 
phy as a system of philosophy began to be forgotten because it was unable to compete with the system of materialistic philosophy which was thought to be more compatible with modern times. However, the word less competitive for perennial philosophy does not mean that it is irrelevant and eventually disappears like some forms of modern philosophical systems. Many people seem to forget perennial philosophy as a proper name, but the key points of thoughts that became the essence of perennial philosophy have still existed and appeared in every new form of thoughts up to contemporary times. In the late $20^{\text {th }}$ and the early $21^{\text {st }}$ century, people, including those who are competent in the field of science, begin to excavate the values of perennial philosophical that they have forgotten for centuries. People use them as frame of reverences or new paradigm to understand and answer the questions of life in the present. Thus, we can conclude that the contemporary age or postmodernism ${ }^{6}$ (see Wora 2006, 93-94; Sugiarto 1996, 15) is the era of the awakening perenial philosophy.

Budhy Munawar Rachman argues that nowadays perennial philosophy is well known to many religious thinkers-especially outside academia-and those who pay great attention to mys-

${ }^{6}$ Postmodernism is a controversial term. On the one hand, this term is often used in a cynical and mocking way, both in art and in philosophy. It is considered as a superficial and empty intellectual method or a mere reactionary reflection of the social changes that are now going on. Postmodernism is one of the most recent phenomena in the contemporary human life; it is a unique phenomenon and is the most exciting issue in the contemporary human life. Postmodernism seems to be understood as a critical phenomenon of modernity. It is a whole enterprise that intends to revise the modern paradigm. One of the most dominant characteristics of postmodernism is diversity or plurality. Sugiarto (1996) categorizes postmodernism into three forms. The first is that the revision of modernity comes in a tendency to return to the pre-modern period. The second category comes in the form of literary thoughts. The third category is any thought that would revise modernism, but not by rejecting it totally. 
ticism and comparative religion (Rahman 1995). With this regard, perennial philosophy is, then, something which in Sayyed Hossein Nasr's term is called rediscovered (Rahman 1995).

Furthermore, perennial philosophy gradually began to affect the academic world in the field of religion characterized by its admission as one of the perspectives of the spiritual world. The development of perennial philosophy now also begins to gain recognition as an alternative in understanding the complexity of interreligious dialogue, as Frederick J. Streng writes in his book entitled Understanding Religious Life. He writes that the perennial view of the spirit, which is the inner identity of religions, has enriched the atmosphere of interfaith relations (Rahman 1995).

Even though in this contemporary era the position of perennial philosophy in the academic world, using a term given by Komaruddin Hidayat, is not glamorous, especially in Indonesia, there is still a hope for its revival, such as in The Journal of The Amarican Academy of Religioun which has published a good article about Fritjfof Schoun by James Cuttinger a few years ago. In deed, the perennial perspective had never been talked beforehand in this professional journal. The publication of this article is an important beginning for the perennial philosophy to enter the academic world as it marks the beginning of appreciation for this perennial philosophy. The dissemination of the perennial philosophical thoughts in several journals mentioned above will hopefully influence and reinforce the position of perennial philosophy in the academic world in the contemporary era. However, this perennial philosophy is known only recently in Indonesia. Komarudin Hidayat, Muhammad Wahyuni Nafis and Arqom Kuswanjono are the ones who popularized the term perennial philosophy in the discussion of Islamic studies in Indonesia. 


\section{Mysticism as a Method to Trace History of Religions}

Mysticism $^{7}$ in English is similar to mystikos in Greek or mysterion derived from the word mystes meaning a person who sought the secrets of reality or myein meaning to close one's own eyes. Mysticism is used by Dionesios Areopagita as a method of approaching the transcendent God (see Bagus 1996; Nasution 1978, 56).

Many scholars have given definitions and distinctive features of mysticism. William James formulates four mystical features: (1) innefability, (2) noetic quality, (3) transiency and (4) passivity. Iqbal, in the other hand, formulates five mystical features: (1) mystical experience is a direct experience, (2) it can not be analyzed, (3) it is a condition of "self-union" with the unique self; (4) it is uncommunicable, and (5) it is temporary but very impactful (Kuswanjono 2006b).

In perennial philosophy, this mysticism is used as an approach to understand the reality of religion and religiosity which are diverse and complex, as well as to explore the historicity and roots of the religiosity of various religions in understanding the divine aspect and ideally finding the meeting point of diversity or pluralism of that understanding to find a transcendental understanding of the One (Kuswanjono 2006b).

Existentially, God is one or single. The problem that arises here is why from a single source emerges a plural understanding

${ }^{7}$ Mysticism in Islam is named tasawuf and by western orientalists is called sufism. The word sufism in western orientalist terms is specifically used for Islamic mysticism. Sufism is not used for mysticism contained in other religions. Tasawuf or sufism has the purpose of acquiring a direct and conscious relationship with God, so that someone realized he is in the presence of God. The essence of mysticism, including sufism, is the awareness of the communication and dialogue between the soul and God by means of seclusion and contemplation. Awareness of being close to God can make a man reach the form of ittihad (united with God). 
and many names in reality. According to John Hick in his book God Got Many Names, he argued: what I mean is that the One eternal is responded by different human cultures and in different forms, either personal or non-personal (Hick 2006). The answer to this question, for the perenialis philosophers, certainly not only by using a logical, rational understanding just as developed by rational philosophers of the Modern tradition, but also by involving a mystical understanding (Kuswanjono 2006b).

According to perennial philosophers, the mystical method used in understanding the ultimate reality of religions and religiosity, i.e. concerned with wisdom necessary in living the righteous life, seems to be the essence of all the great religious teachings and traditions of human spirituality. In relation to religions, the perenial philosophers triy to seek a common vision from the reality of the many to the origin of The One-God, which is given various names by the followers of religions when the radiance of The One is captured by history, culture, civilization, mandsets, and psychological awareness of man or a nation.

The mystical method intended in the perenial philosophy is an experience of God's presence which is unique and individual. This method seeks to reveal the esoteric aspect from the exoteric diversity of each religion. In Islam, this method is called the stage of the Sufi path, which includes three stages, i.e. believing, understanding, and discovering (Iqbal 1983). Iqbal says that when an individual destroys the boundaries of space and time, and takes heed to himself, he will find an awareness of pure mobility in his direct intuition (Kuswanjono 2006b). According to Kuswanjono, on this stage, one is able to observe the source of motion and change in the universe. Later, in this experience, he finds the highest category of reality. In this sense, one can experience the divine direct experience without intermediaries. Through direct experience with God, individuals can make direct contact with Divine essences (Kuswanjono 2006b). 


\section{The Transcendent Unity behind the Diversity of Religions and Religiosity}

As explained above, the term religion in Indonesian society is known as agama or al-din from an Arabic word. In English, French, and German, it is called relegion; in Dutch it is called religie; and in Latin it is religare or relegere which contains several meanings. Augustine argued that relegion consists of the words re and eligare which means to re-elect, i.e. to re-elect a path, from the misguided way to the way of God. Lactantius, in the other hand, argues that relegion consists of re and ligere which means to reconnect the ropes of God and man that broke up for sin. Further, Cicero argues that religion is composed of the word re meaning to read the sacred texts repeatedly, so that the soul is affected by His sanctity. According to Ahmad Tafsir, religion is a belief system and practice in accordance with that belief. It can also be said that religion is the rule of the inner and outer way of life (Tafsir 1990).

Religion, among its followers, is believed to bring a sense of security and peace in life because for them it contains the most adequate guidance of life for men. Religion is a reference to life in its various aspects, including aspects of social life (Kuswanjono 2006b). Religious thoughts in the historical reality are always evolving both in theological and philosophical realms. In the theological realm, although it is believed that the holy book of a religion comes from the Absolute or the One, it is still open the possibility for reinterpretation in understanding its doctrines. The emergence of schools of thought rooted in a particular religion, culture, or human mind, shows that religious understanding is different and always growing (Kuswanjono 2006b).

Religion in the philosophical realm also becomes an interesting topic to discuss because religious discourse always appears along the development of times and thoughts. It is a universal 
and eternal theme throughout the ages, perennial (Kuswanjono 2006b).

The problem of interpretation over religious teachings becomes important to be studied or elaborated. This is because the empirical reality of human life is always and forever faced with the diversity of religious understanding; when religion becomes diverse, it is very vulnerable to cause disunity. In this case, Budhy Munawar Rahman argues that a religion has potentials to create problems when dealing with other religions. The problems can be found, among others, in the truth claim and salvation claim war (Rahman 1995). However, religion can also serve as a unifying factor and a source of inspiration for a civilization, though in another occasion it may cause a human division (Rumadi 2005).

From a sociological point of view, indeed truth claim and salvation claim have made various socio-political conflicts bringing various inter-religious wars, which are still true in this modern time. This is also what leads one to make self-justifying epistemological prejudices and assume his own religion with absolute truth (Rumadi 2005).

Taking into account the above empirical reality, a question arises: is there any transcendent unity behind the diversity religions and religiosity? In seeking answer to the above question, the author traces perennial philosophy which is concerned with the diversity of religions and their transcendent unity described as follows:

a. The diversity of religions and religiosity

The term kebhinnekaan in this paper is an equivalent to pluralism or diversity. Pluralism itself is derived from plural that means many or numerous. It is a form of word used with reference to more than one (Ka'bah 2005). A term that develops in recent years, pluralism as a reality of diversity has existed since the existence of the universe as God created it, and religion and 
religiosity are no exception. From historical-sociological perspective, religious diversity is an unavoidable fact because it is indeed inevitability. In accordance with sunnatullāh, everything in the world is deliberately created with full of diversity, not excluding the religion. The fact that religion is not revealed in the context of space and time has brought about the diversity religions and religiosity as an unavoidable historical reality (Arifin 1996).

As described above, perennial philosophy is also called shopia perennis, a term derived from English equivalent to the Latin term philoshopia perennis (Ridwan Ahmad Hasan; Irfan Safrudin 2011). The word perennis means eternal, everlasting, or forever. Thus, perennial philosophy is also known as the philosophy of immortality (Kuswanjono 2006a). In the contemporary context, perennial philosophical thoughts are widely used to understand the diversity or plurality of religions and religiosity. In this case, religious understanding is not often regarded as one of the factors triggering the split among religious followers due to their excessive internal fanaticism that ignores social factors outside of their religion. Therefore, the next question arises: how does perennial philosophy see or perceive the diversity of religions and religiosity?

In perennial philosophy, the diversity of religions and religiosity is sought their meeting point or common platform in religion, i.e. the esoteric essence in diversity or plurality and exoteric aspect in the existing religions (Kuswanjono 2006b). This philosophy holds that every religion has one form and one substance. The substance has unlimited rights because it is born from the absolute. The absoluteness of a religion lies in its substance and is intrinsic. When a religion confronts another religion, what appears is its form or reality, something which is extrinsically relative. A religion is only one form of the many religions that exist. 
Therefore, when a religion proclaims itself to be absolute, then relative absoluteness arises (Kuswanjono 2006b). This is what Nasr termed as relatively-absolute (Hidayat and Nafis 1995).

Keeping this in view, every religious follower should realize that the absoluteness he believes in his religion is relative when confronted with the absoluteness of religious diversity. Every religious follower has the same right to assume that his religion is the most correct one. Here, perennial philosophy holds that the absolute truth is one. From the One, it radiates various truths, as seen in the case of the sun that will appear red when captured by a rose, green when captured by a leaf, and so does the religion (Kuswanjono 2006b). Religion can contain two meaning: Religion with capital $A$ and religion with small $a$. Religion with small $a$ is an empirical reality that emerges as the radiance of Religion with capital $A$. Truth claims that appear in today's reality of religiosity occur in the level of religion written with small $a$. They claim what is relative, i.e. religion with small $a$, to be absolute, and ignore the religiosity side. They claim that other religions are wrong and, thus, must be rejected (Kuswanjono 2006b).

Esoteric and exoteric ${ }^{8}$ (see Schuon 1994; Hidayat and Nafis $1995,11)$ are an integral duality in religion like the two sides of coin inseparable from one another. Esoterism is substantially universal. However, the exoteric plurality of religion will appear diverse as an embodiment of the esoteric meaning understood by each religion. The existence of truth claim on the level of exoterism as long as it is internal is justified and very necessary because carrying out religious teachings without a belief that

${ }^{8}$ Esoteric is things that can only be known and done by some people from a particular group of religious followers. And exoteric is things that can be known and that is done by all members of a group of religious followers of certain schools. 
the teachings are true is impossible. Then the problem emerges when the claim is external so as to place other beliefs in the position of the opponent. Therefore, in order to avoid conflicts between religious followers, inter-religious dialogue becomes very important, and harmonious communication between religions must be established.

b. Transcendent unity of religions and religiosity

As mentioned above, many people including experts think that there are inevitable differences among religions and religiosity when they are confronted one with another. We, for example, say that Islam and Hinduism are two completely different religions. There is no meeting point between the two, as many people think; these two religions have different social histories (Rahman 1995). In line with that, F. Zaehner, a Christian who is a Hindulogist and Sufi scholar, argues that, instead of unity, there are more conflicts between religions. Some traditional Islamic scholars, like Sayyed Nauguib Al-Attas and Zainuddin Sardar, also reject the transcendent unity of religions (Kuswanjono 2006 b). If so, is there any transcendent unity behind religious diversity?

Unlike Sayyed Nauguib Al-Attas and Zainuddin Sardar, perennial philosophers argue that behind the diversity or plurality of religions is a transcendent unity and similarity. This transcendent unity, according to perennial philosophy, is seen in the common vision, or what in Islam is called the basic message of religion, namely submission to always fear God and live His presence in everyday life (Rahman 1995).

In the context of the diversity of religions and religiousity, the acceptance of the common vision is understood as reconnecting the many, in this case the exoteric reality of religions and religiosity, to the Origin and the One, i.e. God, who is labeled with various names by the religious followers along with the 
cultural development and social and spiritual consciousness of human being. Further, this empirical impression of the plurality of religions and religiosity does not cease to be a factual phenomenon. Instead, from that point, there must be one reality that binds those different religions, or what is in a symbolic language called the religion. This is what Budhy Munawar-Rahman explained.

As described before, religion can contain two meaning: $r e-$ ligion with capital ' $A$ ' and religion with small ' $a$ '. Religion with small $a$ is an empirical reality that emerges as the radiance of Religion with capital 'A' (Kuswanjono 2006b). In line with the above argument, Budhy Munawar Rahman stated that it is important to distinguish Religion capital ' $A$ ' and religion with small ' $a$ '. They are two different things. Budhy Munawar Rahman cited Raimundo Panikkar who compares religion to language. $\mathrm{Hu}-$ mans have Language (with capital letter), but no one can speak the Language (with capital letter). He said, "You should speak in a language (with small letter). You can not have a Religion except in the form of a religion. You can not have a pure Religion, just as you can not speak of a pure Language." Further, Budhy argues that the Religion in this sense is the common vision of the world's religions according to Huston smith. By the parennialists, this term is known as the transcendent unity of religions.

Quoting Frithjof Schuon in his book Islam and Perenial Philosophy, Budhy Munawar Rahman argues that the seemingly opposed religions actually have the same transcendent unity. Indeed, the exoteric form of religions appears to be different or contradictory, but their esoteric form and substance are the same. They have the same intent, that is, as a means of saving the spiritual life of men (Rahman 1995). Bhagavan Das said that we all follow the same path of life. Some come from a distance, and some other come from nearby. All are starving and thirsty; 
all need bread and water of life, which can only be obtained through unity with the Supreme Spirit. According to Budhy, what is described by Bhagavan Das as the road of life is an effort ${ }^{9}$ in Schuon's term.

In Islam, effort is built on the basis that there is only one unique reality, i.e. $t a u b \bar{i}$, whether people understand it in an exoteric or separate way, or in an esoteric way that is both transcendent and immanent. As a result of this view, Budhy Munawar Rahman, quoting Schuon, argues that the Prophet in Islam needs not to be more than a human being, and there is no reason why he should be unique in the presence of other prophets who preceded him. Every prophet carries the same divine message. Islam calls it a surrender or submission (Islam in the genetic sense). These Islamic perennial ideas are common in the Quran and Islamic traditions (Rahman 1995). Meanwhile in Judaism and Christianity, effort is constructed through a confession of an agreement between God and a holy community. Therefore, in this religion, sacrament and Eucharist are needed to create the Holy Community. All creation is centered on monks.

According to Budhy Munawar Rahman, this perennial explanation on effort, of course, brings the 'tradition' to be seen from two perspectives: from the divine perspective, it is a narrative of the origin of all reality. From the human perspective, it is a way back to God, to the Origin.

To strengthen the argument about the existence of the transcendent unity behind the diversity or pluralism in religion and religiosity, perennial philosophy holds that the True God is One, so that all religions emerging from the One are in principle

${ }^{9}$ The term effort by the perennialists is derived from Buddhism to describe a journey of spiritual ascent. It is the way that tells us how to do an ascent from the lower level of existence, namely our everyday life, to the highest level of reality, namely God through mystical experiences and the experience of being united with God (wahdatu al-wujud). 
equal for they come from the same source. This philosophy distinguishes Religion written with capilal $A$ and religion written with small $a$. in religion written with capital $A$, there is only one truth. However, because religion is revealed to humans in historical and sociological spectrum, it serves like the sun that comes in various colors. According to perennial philosophy, each color is the result of the radiant of the One. Thus, each color can not claim that it is the Absolute as he is only an absolute reality. All colors come from the One, as religion comes from the One. Nevertheless, history and culture bring up a variety of different colors and religions. In this case, the difference exists in exoteric level which actually has a transcendent unity on the esoteric level (Kuswanjono 2006b). However, the difference is not a contradictory difference, rather a systemic difference; one part presupposes the other. Therefore, to live a religion perfectly must bring all religions as far as the esoteric dimension of every religious tradition is concerned.

The perennial philosophy as described above holds that behind the diversity or plurality of religions and religiosity, there is a transcendent unity and similarity. To strengthen its arguments, perenial philosophers argue that in every religious realm, there are the laws, sacred symbols, monuments, and doctrines that are sanctioned by the traditional authorities. Prayers associated with a particular religion are all absolute in the religious world. At the heart of every religion is found the the oneness (Hidayat and Nafis 1995) of God authentically.

Here, the One reincarnates into many; He can be found here and there. According to perennial philosophy, this is where the exoteric problem finds its function and meaning. Yet, this exoteric problem is merely a way to the ultimate truth. However, because that way is legitimized by the Absolute, religious behaviors in the exoteric dimension must also be seen as of the 
Absolute doctrines of a religion. Yet, its absoluteness is still in a relative sense (Hidayat and Nafis 1995). That is, although every adherent of religion must absolutize every religion they embrace, it also provides the possibility for other adherents of religion to absolutize the religion they believe in.

In reinforcing his point of view of the existence of the transcendent unity behind religions and religiosity, perennial philosophy also traces the historical facts of the roots of the great religions, i.e. Judaism, Christianity and Islam. According to perennial philosophers, we eventually must admit that the great religions were born out of Abrahamic religions, because from Abraham many prophets gave birth to the three great religions. From Abraham was then born Prophet Ismail and Prophet Ishaq. Of the two descendants are the three major religions: Judaism, Christianity and Islam. Prophet Ishaq gave birth to many prophets, such as Ya'kub, Yusuf, Moses, Aaron, David and Solomon which ultimately led to Isa. Meanwhile, from Prophet Ismail, there is only one who became a prophet, i.e. Prophet Muhammad. This is how recognition of one God (monotheism) by the three great religions originates. Meanwhile, although it is historically difficult to trace the relationship between other religions and Abraham, it does not mean that they do not have the doctrine of monotheism. As we all know, perennial philosophy argues that esoterically the idea of monotheism is found in every tradition of religions. In this esoteric level, dialogue among religions may ultimately lead to the intermingling of the religious teachings. (Hidayat and Nafis 1995)

However, from all that is described above, perennial philosophers in this regard does not mean to unify all religions or create one universal religion. In fact, they mean to open a way to a spiritual ascent through the reviving of the religious traditions that evolve in every religion. Perennial philosophers recognize 
every sacred tradition as something that comes from heaven or God that must be appreciated and treated with high respect.

Perennial Philosophy and Its Relevance to the Context of the Diversity of Religions and Religiosity in Indonesia

Diversity or plurality of religions and religiosity is indeed a sunnatullah. History has noted that great religions are born from a diverse or plural religious community. The Buddha's enlightenment, for example, emerged from a chaos of plurality of Brahmanist, Jaena, materialistic, and dogmatic views (Cowart 1989). Similarly, Islam came in the midst of the diversity or plurality of Christianity, Zoroastrianism, followers of Manicha, Jew, and idol worshipers (Kuswanjono 2006b).

The diversity of religions and religiosity is also seen in Indonesia. History recorded that various religions believing in the one Almighty God have developed and grown up in Indonesia. These religions are like Hinduism, Buddhism, Islam, Christianity, and others. This diversity of religions and religiosity will certainly cre a te a logical consequence of religious problems (Kuswanjono 2006b).

The diversity or plurality of religions is a thing that can not be denied to occur in social life. It is also experienced by other countries with different complexity. This empirical reality of the diversity of religions should not lead to division and violence. The diversity of religions and religiosity in Indonesia has been the main attraction for the outside world. The peaceful diversity of religions has been the characteristic of Indonesia. Indonesia is considered as an alternative model for the realization of religious harmony on Earth (Kuswanjono 2006b). Muhammad Ayoub, a Professor at Temple University, Philadephia, argues: "The experience of religion in Indonesian society compared to other Muslim societies is the model closest to the value of the 
Quran and the Sunnah of Prophet Muhammad saw." (Kuswanjono 2006b; Shihab 1998). However, the peaceful and cool condition of the religious harmony as described above does not last long. Many riots and religious upheavals happen in Indonesia, such as in Ambon, West Kalimantan, Central Kalimantan and Poso of Central Sulawesi (Surur 2003).

Such empirical reality shows the substantial dimension of religion that is not fully understood by most Indonesians. The existence of radical truth claims negates the substantial meaning of religion as a guide to true happiness. Substantially, religion is one because it comes from the One. From this One, truths radiate with relative forms. Kuswanjono maintains that religious fanaticism should refer to fanaticism in a substantive sense, while fanaticism in the form level must be intended to increase the belief of one's religious truths without blaming other religions (Kuswanjono 2006b).

Indonesia should reflect back on history, i.e. on the ancestor's teachings of the noble values of togetherness and the religious harmony as seen in Hindus and Buddhist traditions manifested in a motto "Bhinneka Tungga Ika, Tan Hana Dharma Mangrua" which means different but still one because no one has a different God. This motto contains a very deep meaning. It reveals the exoteric and esoteric meaning of religion, that is, exoterically the diversity or plurality of religions is an undeniable reality. The diversity or plurality must be understood in the context of oneness because, in esoteric level, God the One is the common goal of all religions (Kuswanjono 2006b).

Religious people in Indonesia should return to the political and moral commitment of the nation, namely Pancasila, as a philosophy and a worldview by understanding, appreciating and realizing the values that exist in it. The fundamental values meant here are that those contained in the five silas (principles) of Pancasila are values that are universal and abstract. 
The fundamental values contained in the five principles of Pancasila are as follows (Soejadi 1999):

1. Belief in the one and only God includes:

a. Belief in the existence of the One God as the creator of all things with perfect and holy qualities such as Almighty, All-Merciful, All-Just, Wise, and so on;

b. The devotion to the One God Almighty by keeping all His commandments and staying away from His prohibitions;

2. Just and civilized humanity includes:

a. Recognition of human dignity with all their rights and obligations.

b. Good treatment to fellow human beings, oneself, nature, and God;

c. Humans as a cultured and civilized beings that have creativity, feeling, intention, and belief.

3. The Unity of Indonesia includes:

a. Recognition of the unity in diversity, ethnicities, religion, customs, culture;

b. Recognition of the unity of the nation and territory of Indonesia as well responsibility to defend and uphold the nation.

c. Love and proud of the nation and the state of Indonesia.

4. Democracy guided by the inner wisdom in the unanimity arising of deliberations amongs representatives includes:

a. The state is for the benefit of all the people;

b. Sovereignty is in the hands of the people;

c. Indonesian people as citizens have equal positions, rights, and obligations;

d. The popular leadership is the reason-based wisdom;

e. Decisions are made on the basis of consensus by the people's representatives 
5. Social justice for the whole of the people of Indonesia includes;

a. Fair treatment in all fields of life, e.g. politics, economy, sociality, and culture;

b. The embodiment of social justice is for all the people of Indonesia;

c. Balance between rights and obligations;

d. Respect the property of others;

e. The ideals of a just and prosperous society as well as material and spiritual equality for the entire people of Indonesia.

f. Love of progress and development.

The universal and abstract nature of the Pancasila principles can certainly serve as the foundation for the creation of diversity or plurality of religions in Indonesia. According to Notonagoro, human beings, primarily the Indonesians, are supporters of the Pancasila principles. The possession of the monoplural nature of the personality of the human being, namely physical and spiritual beings, individual and social beings, independent beings and God's creatures, makes it possible for the religious followers to position themselves as the truly God's khalifah on earth bringing peace and prosperity to the universe (Kuswanjono 2006b).

In the context of perennial philosophy, the truth of the Pancasila is not contrary to religion. The principles of Pancasila as described above, especially the first principle, clearly point to the esoteric dimension of God, that is, God's essence is Absolute. It is a necessity for God to be the one and only God, in substance, nature, and deeds. The concept of the oneness of God is a dimension that brings about diversity or pluralism of religiosity (Kuswanjono 2006b).

Concern of the diversity or pluralism of religions and religi- 
osity can be approached with several ways, inter alia: dialogical approach. The dialogue meant here does not mean to be formal and organized in a room, but it is practiced through daily activities, television, newspapers, and books. According to Komaruddin Hidayat and Muhammad Wahyu Nafis, this dialogue must also be done openly and sympathetically, so that each participant seeks to understand the position of other participants. They are expected to see and understand the position of the others from within. The main purpose of this dialogue is to learn from each other and listen to the religious experiences of each of the participants of the dialogue, rather than to compare and search for the most correct religion (Hidayat and Nafis 1995). Kuswanjono, in his book Divinity in the Study of Perennial Philosophy formulates some of the attitudes that must be demonstrated in conducting inter-religious dialogue:

The first is tolerance. Dialogue will not be possible if there is no tolerant attitude of each party. An apriori view that other religious teachings must be wrong is one form of intolerance. The second is parallelism. It is an attitude that recognizes that religions are parallel paths, so that dialogue seeks neither to interfere with the affairs and teachings of other religions nor to make others convert into other beliefs. Rather, it is intended to deepen their religious traditions critically. The third is pluralism. It is both being aware of the existence of religious pluralism and plays an active role to build a sense of togetherness (Kuswanjono 2006b).

Citing Harold Coward, Kuswanjono argues that what can be the basis for dialogues amid today's religious plurality are: First, in all religions, there is experience of a transcendent reality that transcends this world and can not be fully conceptualized by man. Second, the reality is understood in various ways both within each religion and in all religions, and that recognition of 
plurality is necessary both to protect religious freedom and to respect human limitations. Third, the forms of religious plurality serve as a tool or a means, and that the revelations, doctrines, and spiritual disciplines of religions are a means of achieving a transcendent reality. Thus, it is necessary to avoid any truth claims that cause dialogue to be merely a battle or argument about the truth one beliefs. Fourth, due to human limitations and human needs for commitment to a particular experience of transcendent reality, our particular experience will function as a criterion that legitimizes our own personal religious experience. Recognition of the deep religious commitment needs to be felt as an absolute, but it must remain respectful of the absolute religious commitment felt by the others. Fifth, the criticism given or obtained should be constructive, tolerant and aimed at comprehending critically about religious understanding. Sixth, self-critical dialogue must be able to penetrate further into our own particular experience of transcendent reality (Kuswanjono 2006b).

\section{Closing}

From the overall description the author explains, we can sum up some points as follows: First, Perennial philosophy is often identified with different terms, such as: scentia sacra, God's wisdom, traditional wisdom, sanatana dharma, etc. Etymologically, the word perennial comes from a Latin word perennis, which means eternal or forever. Hence, perennial philosophy is also known as the philosophy of eternity.

Second, in order to understand the essentials of religions and religiosity as well as to explore the historical aspect and roots of religiosity, mystical method is required. Perennial philosophers in seeing the diversity or plurality of religions seek to find the transcendent unity or meeting point of religions; they search for 
the esoteric essence in the diversity of the exoteric form in the existing religions.

Three, According to perennial philosophers, behind the diversity or plurality of religions and religiosity is a transcendent unity and similarity. In their argument, this transcendent unity is seen in the level of the common vision, or what in Islam is called the basic message of religion, namely submission to always fear God and live His presence in everyday life. Further, the perennial philosophers also argue that the True God is one, so that all religions emerging from the One are in principle the same for they come from the same source. In other words, the diversity of religions and religiosity exists only on the exoteric level, and all religions actually have a transcendent unity on the esoteric level. However, the perennial philosophers in this case do not mean to unify or equate all religions, rather they try to open a way to a spiritual ascent through the reviving of the religious traditions in every religion.

Four, the perspective of perennial philosophy is highly relevant to the context of the diversity of religions and religiosity in Indonesia. Indeed, the religious condition in Indonesia is diverse, such as Hinduism, Bhudda, Islam, Christianity, and many local beliefs. However, this is, in fact, parallel to the ancestor's teachings of the noble values of the unity and religious harmony as manifested in the motto Bhinneka Tunggal Ika, Tan Hana Dharma Mangrua which means different but still one, as no one has a different God. This motto reveals the exoteric and esoteric meaning of religion, that is, exoterically the diversity or plurality of religions is an undeniable reality. This diversity or plurality of religions must be understood in the context of unity because esoterically the one and only God is the goal of all religions. 
THE TRANSCENDENT UNITY BEHIND THE DIVERSITY

\section{Bibliography}

Abdurrahman. 1993. Agama Dan Masyarakat. Yogyakarta: IAIN Sunan Kalijaga.

Anshori, Endang Saifudin. 1979. Ilmu, Filsafat \& Agama. Surabaya: Bina Ilmu.

Arifin, M. 1992. Menguak Misteri Ajaran Agama-Agama Besar. Jakarta: PT Golden Terayon Perss.

Arifin, Samsul. 1996. Spiritualisasi Islam Dan Peradaban Masa Depan. Yogyakarta: SIPRES.

Bagus, Lorens. 1996. Kamus Filsafat. Jakarta: Gramedia Pustaka Utama.

Baharudin, Muhammad. 2016. Tuhan Dan Agama Dalam Pergumulan. Bandar Lampung: Harakindo Publishing.

Bahtiar, Amsal. 2009. Filsafat Agama: Wisata Pemikiran Dan Kepercayaan Manusia. Jakarta: Rajawali Press.

Cowart, Harold. 1989. Pluralisme: Tantangan Bagi Agama- Agama. Yogyakarta: Kanisius.

Hamersma, Harry. 1983. Tokoh-Tokoh Filsafat Barat Modern. Jakarta: Gramedia.

Hick, John. 2006. Tuhan Punya Banyak Nama. Yogyakarta: Dian/Interfidei.

Hidayat, Komarudin, and M. Wahyu Nafis. 1995. Agama Masa Depan: Perspektif Filsafat Perenial. Jakarta: Paramadina.

Iqbal, Muhammad. 1983. Pembangunan Kembali Alam Pikiran Islam. Edited by Osman Raliby. Jakarta: Bulan Bintang.

Ismail, Fuad Farid. 2005. Mabadi Al-Falsafah Wa Al-Akhlaq Wazarah Al-Tarbiiyyah. Yogyakarta: IRCiSoD.

Ka'bah, Rifyal. 2005. "Nilai-Nilai Pluralisme Dalam Islam.” In Nilai-Nilai Pluralisme Dalam Islam. Bandung: Nuansa. 


\section{BAHARUDIN AND MUHAMMAD AQIL LUTHFAN}

Kuswanjono, Arqom. 1997. "Aktualisasi Filsafat: Upaya Mengukir Masa Depan Peradaban.” Journal of Philosophy Special Ed.

- 2006a. "Filsafat Perennial Dan Rekonstruksi Pemahaman Keberagamaan.” Jurnal Filsafat 1 (1): 95-108.

- 2006b. Ketuhanan Dalam Telaah Filsafat Perinial: Refleksi Pluralisme Agama Di Indonesia. Yogyakarta: Filsafat UGM.

Nasr, Sayyed Hossein. 2004. Intelegensi Dan Spritualitas Agama-Agama. Edited by Suharsono. Depok: Inisiasi Press.

Nasution, Harun. 1974. Islam Ditinjau Dari Berbagai Aspeknya. Vol. I. Jakarta: UI Press.

- 1978. Filsafat Dan Mistisisme Dalam Islam. Jakarta: Bulan Bintang.

Rahman, Budhy Munawar. 1995. "Preface of Book." In Agama Masa Depan Perspektif Filsafat Perennial. Jakarta: Paramadina.

Ridwan Ahmad Hasan; Irfan Safrudin. 2011. Dasar-Dasar Epistemologi Islam. Bandung: Pustaka Setia.

Rumadi. 2005. “Agama Dan Negara: Regulasi Kehidupan Beragama Di Indonesia.” In Nilai-Nilai Pluralisme Dalam Islam. Bandung: Nuansa.

Schmit, Charles B. 1996. "Filsafat Perenial: Dari Steuco Hingga Leibnez.” In Perenialisme, Melacak Jejak Filsafat Perenial, edited by Ahmad Norma Permata. Yogyakarta: Tiara Wacana.

Schuon, Frithjof. 1993. Islam Dan Filsafat Perenial. Edited by Rahmani Astuti. Bandung: Mizan.

Yayaan Obor Indonesia. 
Shihab, Alwi. 1998. Islam Inklusif, Menuju Sikap Terbuka Dalam Beragama. Bandung: Mizan.

Soejadi. 1999. Pancasila Sebagai Sumber Topik Hukum Indonesia. Yogyakarta: Lukman Offiset.

Sugiarto, Bambang. 1996. Posmodernisme Tantangan Bagi Filsafat. Yogyakarta: Kanisius.

Surur, Umar. 2003. "Konflik Sosial Bernuansa Sara Berbagai Komunitas Etnik Di Kalimantan Barat.” In Konflik Sosial Bernuansa Agama Di Indonesia. Jakarta: Departemen Agama RI.

Tafsir, Ahmad. 1990. Filsafat Umum: Akal Dan Hati Sejak Thales Sampai James. Bandung: Remaja Rosda Karya.

Wora, Emanuel. 2006. Perenialisme: Kritik Atas Modernisme Dan Postmodernisme. Yogyakarta: Kanisius. 
This page intentionally left blank 